\title{
Inta Freimane un semantika, sintakse, valodas kultūra
}

\section{Inta Freimane and semantics, syntax, language standardization}

\author{
Andra Kalnača, Ilze Lokmane \\ Latvijas Universitāte \\ Humanitāro zinātṇu fakultāte \\ Latviešu un vispārīgās valodniecības katedra \\ Visvalža ielā 4a, Rīga, LV-1050 \\ E-pasts:andra.kalnaca@lu.lv,ilze.lokmane@lu.lv
}

2018. gada 3. janvāris ir 85 gadu jubilejas diena vienai no pazīstamākajām latviešu valodniecēm - Latvijas Universitātes emeritētajai profesorei Intai Freimanei. Viņa, būdama ilggadēja Latvijas Universitātes docētāja un vienlaikus erudīta valodas teorijas un prakses pētniece, ir uzskatāma par īpašas latviešu valodniecības skolas izveidotāju semantikā, sintaksē un valodas kultūrā, viņas zinātniskās publikācijas un tajās ietvertās idejas ir drošs un neatņemams pamats ikvienam, kurš interesējas par latviešu valodas semantisko un sintaktisko sistēmu, tās funkcionalitāti un īstenošanos valodas praksē. Godinot profesori jubilejā, Latvijas Universitātes Humanitāro zinātņu fakultātes Latvistikas un baltistikas nodaļas Latviešu valodniecības katedra ir sagatavojusi ìpašu Intai Freimanei veltītu viņas kolēǵu, audzēkņu un jaunākās latviešu valodnieku paaudzes rakstu krājumu „Semantika. Sintakse. Valodas kultūra. INTA FREIMANE. SCRIPTUM FESTIVUM”, kurā aplūkots gan profesores dzīvesgājums un darba gaitas, gan analizētas viņas zinātniskās idejas un to turpinājums dažādās valodniecības nozarēs, kā arī ikdienas darba pieredze Latvijas Universitātē.

Krājumā ietverts arī oriǵināls Intas Freimanes pēdējo gadu pētījums par variatīvuma lomu valodas līdzekḷu apritē.

Atslēgvārdi: latviešu valoda; semantika; sintakse; valodas kultūra; valodas sistēmiskums.

Inta Freimane dzimusi 1933. gada 3. janvārī Jūrmalā (plašāk sk. Lokmane 2003). Mācījusies Pumpuru pamatskolā, bet pēc pārcelšanās uz Rīgu - Rīgas 4. pamatskolā, vēlāk Rīgas 5. vidusskolā. No 1952. gada līdz 1957. gadam viña ir Latvijas Valsts universitātes Vēstures un filolog̣ijas fakultātes studente. Inta Freimane atceras, ka tieši interese par literatūru mudinājusi sākt filoloǵijas studijas, tomēr jau pēc pirmā valodniecībā izstrādātā kursadarba par frazeoloǵiju 
Artura Ozola vadībā svaru kauss nosvēries par labu valodniecībai. No studiju laikiem patīkamas atmiņas saistītas arī ar pedagoǵisko praksi - ìpaši paticis strādāt ar vidusskolēniem.

1957. gadā Inta Freimane sāk strādāt LPSR Zinātṇu akadēmijas Valodas un literatūras institūta Vārdnīcu sektorā par laboranti. Lìdzās samērā mehāniskam kartotēku kārtošanas darbam izstrādāti vairāki „Latviešu literārās valodas vārdnīcas” škirịlị. 1960. gadā Inta Freimane iestājas LPSR Zinātņu akadēmijas Valodas un literatūras institūta aspirantūrā. Viņa pievēršas aktuālai un gan semantiskā, gan sintaktiskā aspektā sarežǧìtai tēmai - vienpersonas verbu semantikai un saistāmībai.

No 1964. gada Inta Freimane trīs gadus strādā par redaktori izdevniecībā „Liesma” - vispirms par jaunāko redaktori Enciklopēdiju redakcijā, vēlāk Vārdnīcu redakcijā, visbeidzot par zinātnisko redaktori Oriğinālās daiḷiteratūras redakcijā. Darba biedri atceras viņu kā principiālu, bezbailīgu un atklātu cilvēku. Atmiņā palicis arī viņas sulīgais alts kopīgās dziedāšanas reizēs.

1967. gadā Inta Freimane sāk strādāt par docētāju Latvijas Valsts universitātes Latviešu valodas katedrā. Tajā pašā gadā aizstāvēta kandidāta disertācija „Vienpersonas verbi mūsdienu latviešu literārajā valodā” (pēc Latvijas Republikas neatkarības atjaunošanas 1992. g. nostrificēts kā filolog̣ijas doktora grāds). Latvijas Universitātē pavadīta lielākā daḷa darba mūža - 35 gadi. 1976. gadā Inta Freimane ievēlēta par docenti. 1993. gadā viņai piešķirts habilitētā doktora grāds par monogrāfiju „Valodas kultūra teorētiskā skatījumā”, un no 1994. līdz 2001. gadam viņa ir Latvijas Universitātes Filoloǵijas fakultātes Baltu valodu katedras profesore, bet kopš 2001. gada - Latvijas Universitātes emeritētā profesore.

Intas Freimanes zinātniskā darbība noritējusi ciešā saistībā ar pedagoga darbu LU Filologiijas fakultātē. Sagatavoti daudzi studiju kursi, kas devuši plašu skatījumu uz dažādu valodas līmeņu parādībām - baltu filolog̣ijas specialitātes studentiem docēta mūsdienu latviešu literārās valodas sintakse, interpunkcija, valodas kultūras pamati, valodas kultūras teorija, kā arī vairāki speciālkursi par verbu semantiku un saistāmību, latviešu valodas skaņu verbiem, funkcionālām atkāpēm no latviešu literārās valodas normām, aktuāliem leksikogrāfijas un vienkārša teikuma sintakses jautājumiem. Citu specialitāšu studentiem docēta arī fonētika, ortoepija, grafētika, ortogrāfija un morfolog̣ija. Šie kursi rūpīgi gatavoti, papildināti un padziḷināti daudzu gadu garumā, tā apliecinot atziņu, ka docētājam jāmācās visu mūžu. Saviem jaunajiem kolēg̊iem Inta Freimane ne reizi vien atgādinājusi, ka docētājam jāzina vismaz desmit reižu vairāk par to, ko viṇš stāsta auditorijā.

Filolog̣ijas studenti Intu Freimani atceras kā ļoti prasīgu un reizē labvēlīgu pētniecisko darbu vadītāju. Studenti Intas Freimanes vadībā regulāri piedalījušies zinātnisko darbu konkursos, lasījuši referātus zinātniskās konferencēs, vingas vadībā izstrādāti un aizstāvēti divi promocijas darbi - Ilzes Lokmanes 
„Konsituatīvo saistījumu semantika mūsdienu latviešu valodā” (2005) un Intas Urbanovičas „Paronīmija latviešu valodas paralēlismu sistēmā. Sufiksālā paronīmija” (2012). Inta Freimane arvien bijusi priecīga par jaunām idejām un uzsvērusi, ka skolniekiem jāiet tālāk par skolotāju. Gluži tāpat viņa nesavtīgi iedrošinājusi un atbalstījusi jaunos kolēgeus - reizēm svarīgs bijis uzmundrinājums, citkārt lieti noderējuši gatavi materiāli darbam auditorijā vai nodarbību gaitas plānošanas un īstenošanas ieteikumi.

Inta Freimane allaž bijusi rūpīga zinātnisko darbu recenzente. Recenzijas par studentu darbiem ir dziḷas, būtiskas un reizē labvēlīgas. Dažkārt tās bijušas tik garas, ka aizstāvēšanas sēdē nav pilnībā nolasāmas. Ne vienu vien topošu filologu tās mudinājušas strādāt nopietnāk, pētīt dziḷāk, bet dažam varbūt likušas apzināties, ka recenzents pētìjuma analīzē ieguldījis vairāk darba nekā autors tā tapšanā.

Intas Freimanes zinātniskos darbus raksturo stingri sistēmiska pieeja, uzskatu plašums un novatoriskums (publikāciju kopskaits - ap 70). Tie ir informatīvi piesātināti, tāpēc lasāmi lēni un uzman̄̄gi, rosina diskusiju un sniedz idejas turpmākiem pētījumiem. Jubilejas reizē pieminami galvenie zinātniskā darba virzieni.

Verbu semantiskā klasifikācija un saistāmība, valences teorija. Intas Freimanes doktora (tolaik - kandidāta) disertācijas tapšanas laikā sagatavotas vairākas publikācijas par vienpersonas verbiem. Igauņu valodnieks Pauls Ariste Intai Freimanei ieteicis pētījumu par vienpersonas verbiem publicēt kādā lielā starptautiskā valodā, tomēr tā laika ierobežojumu dẹḷ tas nav bijis iespējams. Pēc disertācijas aizstāvēěanas pētījumi turpinās, problemātika skatīta visā valodas sistēmā. İpaši pētītas vairākas verbu leksiski semantiskās grupas runāšanas verbi un skaņu verbi -, publicēti plašāki raksti, piem., „Verbu tematiskā klasifikācija un saistāmība” (1975)1, „Runāšanas verbu saistāmības īpatnības” (1976)², monogrāfijas „Latviešu valodas skaņu verbi” (1983), „Latviešu valodas skaņu verbi: distributīvs raksturojums” (1984). Šajos pētījumos skatīti latviešu valodas verbu semantikas un semantiskās klasifikācijas jautājumi, to sistēmiskās (paradigmatiskās) un saistāmības (sintagmatiskās) īpatnības. Izmantojot komponentu analīzes un opozīciju metodi, kā arī saistāmības analīzi, izstrādāta verbu semantiskās analīzes un klasifikācijas sistēma, kas izmantojama gan citu verbu (un pārējo vārdšksiru) tematisko grupu pētījumos, gan praktiskajā leksikogrāfijā. Visplašākais skatījums uz verbu personas kategoriju, tās sintaktisko un semantisko aspektu ietverts monogrāfijā „Trešā persona latviešu verbu sistēmā” (2008).

Sk. Intas Freimanes nozīmīgāko publikāciju sarakstu šī krājuma 16. lpp.

2 Intas Freimanes devums runas verbu teorijā plašāk analizēts šì krājuma rakstā: Polkovnikova, Svetlana. Runāšanas verbu izpēte Intas Freimanes darbos. 
Vienkārša teikuma sintakses teorija. Te Inta Freimane turpina un reizē papildina Artura Ozola un Jūlija Kārkliņa sintakses teorijas, radoši izmantodama arī slāvu (galvenokārt čehu un krievu) gramatikā sastopamās strukturālisma un funkcionālisma idejas. Tapusi monogrāfija un reizē mācību līdzeklis „Vienkāršs teikums un tā paplašināšana” (1985), raksti par tādiem joprojām aktuāliem un fundamentāliem sintakses jautājumiem kā vienkārša teikuma paradigma, sintakses līmeņi un tiem atbilstošās sintakses vienības, determinantu problēma sintakse $\bar{e}^{-3}$ un citi. Intas Freimanes sintakses teorijai raksturīgs konsekvents sistēmiskums, kā arī gramatikas formālā un semantiskā aspekta sintēze.

Valodas kultūras teorija ${ }^{4}$. Monogrāfija „Valodas kultūra teorētiskā skatījumā” (1993) ir pirmais plašākais un joprojām vienīgais šāda veida pētījums latviešu valodniecībā. Par pamatu ņemot čehu valodnieku atzinumus un izmantojot arī citu tautu valodnieku pētījumus, Inta Freimane ir izstrādājusi oriǵinālu koncepciju valodas kultūras teorijas galvenajos jautājumos: valodas normas principu, kritēriju un avotu, bet it îpaši to sistēmiskuma izpratnē, literārās valodas variatīvuma un ar to saistītajā paralēlismu teorijā. Te nav valodas kopējiem dažkārt piedēvētās un kritizētās uzskatu šaurības un turēšanās pie iesīkstējušiem uzskatiem. Inta Freimane (1993, 144) uzsver, ka senākais ideāls - pilnīgi vienota, vienveidīga, stabila literārā valoda - ir nepatiess un neiespējams:

„Normētājam jābūt tālredzīgam, kompetentam un atturīgam. Galvenais nosacījums: nereglamentēt, neunificēt variantus pirms laika, pię̧aut paralēlformas un nerīkoties pretī valodas attīstības tendencēm. Šāda nostāja ir pamatota: vardarbība jautājumus neatrisina, tā tikai padziḷina konfliktus.”

Tādējādi no pētījuma izriet secinājums, ka arī pašas autores izteiktie ierosinājumi nav uztverami kā dogma, daḷa no tiem valodas attīstības gaitā var tomēr izrādīties nelietderīgi un ar laiku būtu pārskatāmi. Īpaši mūsdienīgi skan atziņa, ka normētai valodai nav nekādas vērtības, ja valodas līdzekḷi nav iederīgi. Valoda jāizmanto radoši, to nedrīkst padarìt sterilu un trafaretu, tomēr jaundarinājumiem jābūt tādiem, kas valodas sistēmu nevis ārda, bet stiprina un modernizē. Koncentrētā izteiksme, detalizētā un zinātniski pamatotā klasifikācija padara Intas Freimanes monogrāfiju par vērtīgu lasāmvielu filologiem un par pamatu turpmākam - gan praktiskam, gan teorētiskam - darbam valodas kultūrā, bet bagātīgais faktu vākums un pamatotās rekomendācijas ḷauj to izmantot arī par rokasgrāmatu valodas praksē.

3 Par determinanta problēmu sintaksē plašāk sk. šì krājuma rakstu: Saulīte, Baiba. Determinants un situants latviešu valodā un to novietojums teikumā.

${ }^{4}$ Par Intas Freimanes ieguldījumu valodas kultūras teorijas izveidē un attīstībā plašāk sk. šì krājuma rakstu: Urbanoviča, Inta. Intas Freimanes devums latviešu valodas kultūras kā zinātnes nozares attīstībā. 
Gatavojot Intai Freimanei veltīto jubilejas krājumu, bija svarīgi aptvert visus trīs profesores zinātniskās darbības tematiskos lokus, vienlaikus pievienojot arī atsauci uz citām viņas darbības jomām - leksikogrāfiju un pedagog̣iju. Latvijas Universitātes Humanitāro zinātņu fakultātes Latvistikas un baltistikas nodaḷas Latviešu un vispārīgās valodniecības katedras sagatavotajā krājumā „Semantika. Sintakse. Valodas kultūra. INTA FREIMANE. SCRIPTUM FESTIVUM” ir 15 rakstu, kas izkārtoti trīs sadaḷās. Rakstu autori ir Intas Freimanes kolēg̣i, audzēkṇi un klausîtāị Latvijas Universitātē un citās zinātniskās institūcijās, kā arī valodnieki, kas zinātniskās gaitas sākuši jau pēc profesores pensionēšanās, taču savos pētījumos vai nu izmanto valodnieces piedāvātās idejas, vai arī ir saistīti ar kādu no viņas darbības jomām.

Pirmo sadaļu DE IUBILATRICE (PAR JUBILĀRI) veido Andras Kalnačas un Ilzes Lokmanes (Latvijas Universitātes Humanitāro zinātņu fakultāte) krājuma ievadraksts „Inta Freimane un semantika, sintakse, valodas kultūra”, kurā sniegts ieskats jubilāres dzìvesgājumā un raksturoti galvenie zinātniskās darbības virzieni, kā arī aplūkota jubilejas krājuma koncepcija. Sadaḷā iekḷauta arī Intas Freimanes nozīmīgāko zinātnisko publikāciju (monogrāfiju un rakstu) bibliogrāfija.

Otrajā sadạ̣ā IUBILATRIX IPSA (JUBILĀRE PATI) ietverts Latvijas Universitātes emeritētās profesores Intas Freimanes pēdējo gadu orig̣ināls pētījums „Variatīvuma loma valodas līdzekḷ̂u apritē”, kurā plašā skatījumā aplūkota daudzveidīga un sistēmiska valodas funkcionēšana, kā arī šo funkciju nosacīta valodas variēšanās dažādās mikrosistēmās saistībā ar valodas līdzekḷlu konkrētu lietojumu. Tā kā Inta Freimane ar referātiem regulāri piedalīịusies LU Humanitāro zinātņu fakultātes latviešu un baltu valodnieku rīkotajās konferencēs un semināros (it īpaši - prof. Artura Ozola dienā, piem., 2012., 2014., 2016. g.), tad, protams, arī aktīvs zinātniskais darbs valodas sistēmas un jo īpaši latviešu valodas semantiskās un sintaktiskās struktūras, kā arī valodas līdzekḷ̂u funkcionālās aprites izpētē.

Trešā sadaḷa - LAUDATIO IUBILATRICIS (JUBILĀRES SUMINĀ$J U M S)$ - ir visplašākā, jo tajā apkopots 12 valodniecei Intai Freimanei veltītu daudzveidīgas tematikas rakstu. Sadaḷu ievada Ilzes Rūmnieces (LU Humanitāro zinātņu fakultāte) veltījums - sešu latviešu tautasdziesmu tulkojums latīniski rakstā „Klasiskās valodas latviešu dziesmām: latịnu gadījums”. Turot prātā Intas Freimanes mūzikas mīlestību, vokālo izglìtību un jau iepriekš pieminēto skan̄̄go alta balsi, Ilzes Rūmnieces dāvanu jubilārei varam salīdzināt ar greznu piespraudi pie svētku tērpa, proti, jubilejas krājuma.

Pārējie 11 jubilejas krājuma raksti ir saistīti ar Intas Freimanes zinātniskās darbības virzieniem. Semantikas (un vienlaikus arī sintakses) problemātikai veltīti četri pētījumi - Svetlanas Polkovņikovas (Daugavpils Universitāte) „Runāšanas verbu izpēte Intas Freimanes darbos”, Guntas Nešpores-Bērzkalnes (LU Matemātikas un informātikas institūts) „Trešās personas verbu 
saistāmība ar g̊enitīvu: „Līdzsvarotā mūsdienu latviešu valodas tekstu korpusa” dati”, Evelīnas Zilgalves (LU Humanitāro zinātņu fakultāte) „Ne un $n \bar{e}$ sintaktisko un semantisko funkciju sastatījums”, Laumas Šimes (LU Humanitāro zinātņu fakultāte) „Japāņu valodas nominalizēšanas partikula no (の) un tās atbilsmes latviešu valodā”.

Sintakses jautājumus aplūkojuši trīs autori - Linda Lauze (Liepājas Universitāte) „Vārdu secība mutvārdu izteikumos ar apzīmētāju un pielikumu”, Baiba Saulīte (LU Matemātikas un informātikas institūts) „Determinants un situants latviešu valodā un to novietojums teikumā” un Dens Dimiņš (Islandes Universitāte) „Dažas latviešu valodas verbu konstrukcijas ar priedēkḷa dubultojumu ar prievārdu vai apstākḷa vārdu”"

Valodas kultūras teorijas un prakses tematika analizēta trīs rakstos - Intas Urbanovičas (LU Humanitāro zinātņu fakultāte) „Intas Freimanes devums latviešu valodas kultūras kā zinātnes nozares attīstībā”, Anitas Butānes (LU Latviešu valodas institūts) „Latviešu un lietuviešu valodas piemēri ārzemju autoru kalku pētījumos”, Emīlijas Mežales (LU Humanitāro zinātņu fakultāte) „Sarunvalodas stila jēdziens: kopīgais un atškikīgais latviešu un somu valodā”.

Konceptuāli leksikogrāfijas jautājumi apskatīti Santas Jērānes (LU Latviešu valodas institūts) pētījumā „Vārdnīcu struktūras koncepcijas: pamatprincipi un varianti”, savukārt Regīna Kvašìte (Regina Kvašytè, Šauḷu Universitāte) rakstā „Agrīnā otrās baltu valodas mācīšana: semantiskās paralēles” pievērsusies valodu apguves un sastatāmās semantikas tematikai.

Rakstu krājums „Semantika. Sintakse. Valodas kultūra. INTA FREIMANE. SCRIPTUM FESTIVUM" būs noderīgs ne tikai kā mūsdienīgas valodniecības teorijas izmantojuma avots, bet arī kā mācību līdzeklis dažādos latviešu, vispārīgās valodniecības u. c. studiju kursos.

Krājuma sastādītājas pateicas visiem autoriem un recenzentiem par atsaucību un ieguldīto darbu LU emeritētās profesores Intas Freimanes jubilejas krājuma sagatavošanā, Latvijas Universitātes Humanitāro zinātņu fakultātei un Latvistikas un baltistikas nodaḷai, kā arī LU Akadēmiskajam apgādam. Īpaša pateicība pienākas arī LU Humanitāro zinātņu fakultātes Latvistikas un baltistikas nodaḷas vadītājam Ojāram Lāmam (arī - Intas Freimanes audzēknim) un Evelīnai Zilgalvei.

Krājuma izdošana finansēta no LU projekta „Letonika, diaspora un starpkultūru komunikācija” Humanitāro zinātņu fakultātes apakšprojekta „Humanitārā doma - valoda, teksts, kultūra” līdzekḷiem.

Rakstu krājuma „Semantika. Sintakse. Valodas kultūra. INTA FREIMANE. SCRIPTUM FESTIVUM” sagatavošanas beigu posmā - 2017. gada 18. septembrī - saņēmām ziņu, ka profesore devusies mūžībā... Tā kā krājums veidots kā dāvana Intai Freimanei 85 gadu jubilejā, nolēmām tajā neko nemainīt. 
Krājumā paliek pašas jubilāres rūpīgi gatavotais raksts un nozīmīgāko publikāciju saraksts, kā arī viņas 2017. gada jūnija beigās izraudzītās fotogrāfijas.

\section{Literatūra}

1. Freimane, Inta. 1993. Valodas kultūra teorētiskā skatījumā. Rīga: Zvaigzne.

2. Lokmane, Ilze. 2003. Intai Freimanei - 70. Baltu filoloğija. XII (1). Rīga: Latvijas Universitāte, 161-163.

\section{Summary}

Professor emeritus (University of Latvia) Inta Freimane is one of the most prominent Latvian linguists. On January 3, 2018 she would have celebrated her $85^{\text {th }}$ anniversary. Her colleagues and former students at the University of Latvia, aas well as representatives of younger generation of Latvian linguists who started their work in recent years following in the footsteps of their distinguished colleague have prepared the collection of articles „Semantika. Sintakse. Valodas kultūra. INTA FREIMANE. SCRIPTUM FESTIVUM" (Semantics. Syntax. Language standardization. INTA FREIMANE. SCRIPTUM FESTIVUM), which is devoted to the research areas covered by Professor Freimane. The volume also includes a recent original investigation „Variatīvuma loma valodas līdzekḷu apritē" (The role of variation in the circulation of language resources) by Professor Inta Freimane. 